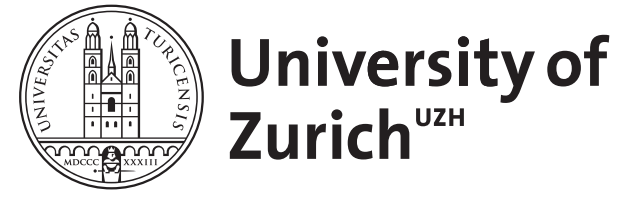

Zurich Open Repository and Archive

University of Zurich

University Library

Strickhofstrasse 39

CH-8057 Zurich

www.zora.uzh.ch

Year: 2011 Legal framework for the single window concept in ASEAN : A successful
movement towards trade facilitation in East Asian countries

Weber, Rolf $\mathrm{H}$

Posted at the Zurich Open Repository and Archive, University of Zurich

ZORA URL: https://doi.org/10.5167/uzh-61282

Journal Article

Published Version

Originally published at:

Weber, Rolf H (2011). Legal framework for the single window concept in ASEAN : A successful movement towards trade facilitation in East Asian countries. Asian Journal of Law and Economics, 2(4):1-24. 


\section{Asian Journal of Law and Economics}

\section{Legal Framework for the Single Window Concept in ASEAN: A Successful Movement towards Trade Facilitation in East Asian Countries}

Rolf H. Weber, University of Zurich and University of Hong Kong

\section{Recommended Citation:}

Weber, Rolf H. (2011) "Legal Framework for the Single Window Concept in ASEAN: A Successful Movement towards Trade Facilitation in East Asian Countries," Asian Journal of Law and Economics: Vol. 2: Iss. 4, Article 2.

DOI: $10.1515 / 2154-4611.1060$

C2012 De Gruyter. All rights reserved. 


\title{
Legal Framework for the Single Window Concept in ASEAN: A Successful Movement towards Trade Facilitation in East Asian Countries
}

\author{
Rolf H. Weber
}

\begin{abstract}
The Single Window concept refers to an «exchange» facility that allows parties involved in trade and transport to lodge standardized information and documents with a single entry point to fulfill all import, export, and transit-related regulatory requirements. The implementation and use of up-to-date Information and Communication Technologies (ICT) facilitates trade and a Single Window should lead to a close co-operation between all involved governmental authorities and agencies as well as the trading community.
\end{abstract}

KEYWORDS: Single Window Concept, ASEAN, Information and Communication Technologies

Author Notes: I would like to thank my research assistant, Rainer Baisch, MLaw, for his valuable support in the preparation of this paper. 
Weber: Legal Framework for the Single Window Concept in ASEAN

\section{Introduction*}

\subsection{Notion of Single Window}

The Single Window concept refers to an «exchange» facility that allows parties involved in trade and transport to lodge standardized information and documents with a single entry point to fulfil all import, export, and transit-related regulatory requirements ${ }^{1}$. The technical models were discerned from a review undertaken by the UN/CEFACT International Trade Procedures Working Group ${ }^{2}$ of various systems that are currently in place or being developed ${ }^{3}$. The three basic models for the Single Window are $^{4}$ :

- A single authority receiving information and disseminating this information to all relevant governmental authorities, as well as co-ordinating controls to prevent undue hindrance in the logistical chain;

- A single automated system for the collection and dissemination of information, thereby integrating the electronic collection, use, and dissemination (and storage) of data related to trade crossing the border;

- An automated information transaction system through which a trader can submit electronic trade declaration to the various authorities for processing and approval in a single application.

1 See for an overview of single-window facilities and services being offered: UN/CEFACT single window repository, http://www.unece.org/cefact/single_window/welcome.htm.

2 See http://www.unece.org/cefact/forum_grps/itp/welcome.htm.

3 The UN/ CEFACT (United Nations Centre for Trade Facilitation and Electronic Business) has factored the concept of a single window for international trade in their efforts to improve the ability of business, trade and administrative organizations to exchange products and relevant services effectively. The support of activities to foster such improvements in developed, developing and transitional economies is focused on increasing the efficiency exchanging products and relevant services by facilitating national and international transactions through the simplification and harmonisation of processes, procedures and information flows. See http://www.unece.org/cefact/ for further information.

4 United Nations Center for Trade Facilitation (UN/CEFACT): Recommendation and Guidelines on Establishing a Single Window, Recommendation, № ${ }^{\circ}$ 33. New York and Geneva, available at http://www.unece.org/cefact/recommendations/rec33/rec33 trd352e.pdf (2005), 7 seq. 
The implementation and use of up-to-date Information and Communication Technologies (ICT) facilitates trade and a Single Window should lead to a close co-operation between all involved governmental authorities and agencies as well as the trading community ${ }^{5}$. Furthermore, notwithstanding a certain harmonization of practices, each country will keep its own unique requirements and conditions. In principle, for efficiency considerations each country should establish a lead agency being responsible for a Single Window.

The technical development of the Single Window concept has now been on the way for a number of years. The main drivers have been organizations such as the United Centre for Trade Facilitation and Electronic Business (UN/CEFACT) and the World Customs Organization (WCO), having focussed on the general benefits and technical aspects of "paperless trade" are:

- UN/CEFACT: Recommendation No. 33, Recommendation and Guidelines on establishing a Single Window to enhance the efficient exchange of information between trade and government (July 2005) ${ }^{7}$;

- UN/CEFACT: Recommendation No. 35, Establishing a legal framework for international trade Single Window (October 2010) ${ }^{8}$.

In the meantime, the ASEAN Secretariat has developed a broad Asean Single Window (ASW) model for simplifying and streamlining customs processing while taking into account the needs of other

5 A paper-based Single Window system may be an alternative for some countries: "A Single Window does not necessarily imply the implementation and use of high-tech information and communication technology (ICT), although facilitation can often be greatly enhanced if Governments identify and adopt relevant ICT technologies for a Single Window." See Rec33 (supra note 4), 3.

6 See http://www.wcoomd.org/sw.htm.

7 Rec33 (supra note 4) was issued to stimulate the creation of single windows throughout the world and to enhance the efficient exchange of information between trade and government. The Recommendation describes a single window as: "a facility that allows parties involved in trade and transport to lodge standardized information and documents with a single entry point to fulfill all import, export, and transit-related regulatory requirements."

8 Recommendation $\mathrm{N}^{\circ} .35$ - Establishing a legal framework for international trade Single Window, available at

http://www.unece.org/cefact/recommendations/rec35/Rec35_october2010_REV2_Final_Eng1 ish.pdf (2010). 
stakeholder groups ${ }^{9}$. The ASW, once operational, will be one of the key elements in the ASEAN member states efforts to create an integrated economic community by $2015^{10}$. The World Trade Organization (WTO) has also received numerous submissions regarding the Single Window for international trade in its current Negotiation on Trade Facilitation.

In practical terms, the Single Window aims to expedite and simplify information flows between trade and government and bring meaningful gains to all parties involved in cross-border trade. The lead agency should assume the function to channel the relevant information to the appropriate (concerned) governmental authorities and agencies in order to support the co-ordination of controls. In addition, the Single Window may provide facilities for payment of relevant duties, taxes and fees.

Obviously, the introduction of a Single Window requires the preparation of a feasibility study in order to analyse the needs and determine its potential scope, the level and nature of demand, data and other information requirements, legal issues, options for implementation, potential for and nature of a pilot implementation, cost for implementation under different scenarios, other resources required (human, technical, etc.), potential benefits and risks, time frame, implementation and management strategy. From a legal point of view, the basic framework must encompass the introduction of privacy laws and rules providing for confidentiality and security in the exchange of information ${ }^{11}$.

\subsection{Benefits of Single Window}

A Single Window can simplify and facilitate the process of providing and sharing the necessary information to fulfil trade-related regulatory requirements for both traders and authorities to a considerable extent. The use of such a system might result in improved efficiency and effectiveness

9 See: http://www.aseansec.org/Fact\%20Sheet/AEC/2007-AEC-007.pdf; http://www.aseansec.org/18005.htm;

http://asean-us-partnership.org/tag/asean-single-window/.

10 See Joint Media Statement of the 15th ASEAN Finance Ministers' Meeting, Bali, Indonesia, 8 April 2011, available at http://www.aseansec.org/26157.htm, Nr. 16.

11 See detailed informations in: WILLIAM LUDDY, ASEAN Single Window - The Intersection of Law \& Technology, available at http://pdf.usaid.gov/pdf docs/PNADM816.pdf. 
of official controls and in reduction of costs for both traders and governments due to better use of resources ${ }^{12}$.

The benefits of the Single Window concept encompass the implementation of a better risk management, the improvement of levels of security and increased revenue yields with enhanced trader compliance, the transparent and predictable interpretation and application of rules, the better deployment of human and financial resources as well as the achievement of gains in productivity and competitiveness. The main elements concern advanced information and risk analysis ${ }^{13}$.

A Single Window can also lead to a better combination of existing governmental systems and processes ${ }^{14}$, while at the same time promoting a more open and facilitative approach to the way in which governments operate and communicate with businesses. Efficient systems with accurate validation schemes will also result in better co-ordination and cooperation between the governmental authorities involved in trade-related activities. Furthermore, the implementation of a payment system within the Single Window ensures rapid and accurate payment to governmental authorities and agencies for required duties and any other charges.

A Single Window can also provide up-to-date information regarding tariff rates and other legal and procedural requirements which will reduce any unintentional errors and increase trader compliance ${ }^{15}$. Through a Single Window both human and financial resources will be reduced, enabling governments to re-deploy resources previously used for administrative tasks to areas of greater concern and importance.

As far as the trading community is concerned, a Single Window is in a position to provide a trader with a single point for the one-time submission of all required information and documentation to all governmental agencies involved in export, import or transit procedures. Traders should benefit from faster clearance and release times, enabling them to speed up the supply chain ${ }^{16}$. Additionally, the improved transparency and increased predictability might further reduce the potential for corrupt behaviour from the public and private sector.

\footnotetext{
12 See generally, the UN/ECE Single Window Repository at http://www.unece.org/cefact/single_window/welcome.htm.

13 See Rec35 (supra note 8), 5.

14 See Rec33 (supra note 4), 10.

15 See Rec33 (supra note 4), 11.

16 See Rec33 (supra note 4), 11.
} 
Weber: Legal Framework for the Single Window Concept in ASEAN

In the meantime the National Trade Single Window is a concept that has been well established in the minds of policy makers and implementers of trade facilitation. At the same time it is important to note that a sufficient number of documents and transactions must be exchanged in order to provide for real return on investment ${ }^{17}$.

\section{Legal Framework for Single Window}

\subsection{International Standards}

The efficiency of a Single Window will increase with the application of internationally accepted standards ${ }^{18}$. Relevant standards have been developed by intergovernmental agencies and international organizations such as the United Nations Economic Commission for Europe (UNECE), United Nations Conference on Trade and Development (UNCTAD), World Customs Organization (WCO), International Maritime Organization (IMO), International Civil Aviation Organization (ICAO) and the International Computing Centre (ICC) ${ }^{19}$. The use of standards and available tools will help ensure that the systems developed to implement the Single Window are more likely to be compatible with similar developments in other countries, and could also help in the exchange of information between such facilities over time ${ }^{20}$.

Since Single Window concepts are designed for Business to Government (B2G) and Government to Government (G2G) relations;

17 Johan POnTÉn, Single Window - Best Practice and the Way Forward (2011), available at http://www.uncitral.org/pdf/english/colloquia/EC/Ponten_SW_Best_Practice_and the_Way_ Forward.pdf.

18 See Symposium Conclusions, UN/CEFACT Symposium on Single Window Standards and Interoperability, (Geneva, May 3-5, 2006), available at

http://www.unece.org/trade/workshop/sw 2006/sw conclusions.pdf. In general to the efficiency advantage of international standardization see ROLF H. WEBER, Regulatory Models for the Online World (Zürich 2002), 118 seq.

19 See Rolf H. Weber, International E-Trade, The International Lawyer, Vol. 41 (No. 3, 2007), 845 seq., 863 seq.

20 Regarding ICT UNCITRAL (United Nations Commission on International Trade Law), has completed a major international convention and several Model Laws that provide important guidance and set an international standard in the field of electronic commerce law. To the extent that having an "e-Commerce-ready legal environment" is important to trade and business development (i.e., an enabling legal infrastructure) as well as important to the use of ICT for national and international Single Window facilities, the UNCITRAL texts provide important international policy guidance. 
thereby, special attention must be paid to the fact that their operation is interoperable with existing solutions in Business to Business (B2B). The United Nations have a long tradition in legal codification related to electronic commerce, in particular through the efforts of the United Nations Commission on International Trade Law (UNCITRAL) ${ }^{21}$; these internationally harmonized guidelines should be considered as benchmark for developing the Single Window legal infrastructure for both national and international transactions.

\subsection{Overview over the Legal Issues}

The establishment of a national Single Window concept has to address the following (not exhaustively listed) topics ${ }^{22}$ :

- Legal basis in state law for the implementation of a Single Window facility;

- Establishment of an appropriate organizational structure for the implementation and operation of a Single Window facility;

- Implementation of proper identification, authentication and authorization procedures;

- Legal framework for proper data protection mechanisms, including rules on rights for authorities and market participants to demand data from the Single Window facility and the on data sharing between governmental agencies and private organizations;

- Procedures for electronic archiving and the creation of audit trails in electronic systems;

- Relevant measures to be put in place in order to ensure the accuracy and integrity of data, for example by electronic signatures, combined with rules designing the responsibility of actors for the accuracy and integrity of such data;

transactions;

- Rules on electronic contracting and execution of

21 UNCITRAL's is the "core legal body of the United Nations system in the field of international trade law". To assist the progressive harmonization and unification of the law of international trade UNCITRAL "is formulating modern, fair, and harmonized rules on commercial transactions". See http://www.uncitral.org/uncitral/en/about us.html.

22 See BART W. SCHERMER, Legal Issues of Single Window Facilities for International Trade, available at http://www.uncitral.org/pdf/english/congress/Schermer.pdf (2007). 
Weber: Legal Framework for the Single Window Concept in ASEAN

- Rules on liability issues derived from activities in the context of Single Window operations;

- Rules on database ownership and on other intellectual property issues;

- Measures avoiding of anticompetitive effects of Single Window operations;

- Mechanisms for dispute resolution.

The broad range of legal topics does not allow considering the details of each legal issue; hereinafter, light will be shed on a few important aspects.

\section{Specific Legal Issues' Areas}

\subsection{Electronic Documentation}

\section{a) Information Security}

Single Window participating governments are responsible for protecting the security of the data and the privacy of personal data in their information systems. The successful implementation of any e-business transactions makes it necessary to establish a secure technical framework for their execution $^{23}$. In fact, information security protection must be commensurate with the risk and magnitude of the harm resulting from the unauthorized access, use, disclosure, theft or loss of sensitive information collected or used in the system ${ }^{24}$.

Information technology knows different schemes providing for the respective security environment. The most well-known scheme is the ACID framework (atomicity, consistency, isolation, durability) ${ }^{25}$. The ACID framework gives a set of properties guaranteeing that database transactions are processed reliably. There are two popular families of

\footnotetext{
23 "If there is a substantial risk that these digital assets will be lost during the traffic phase or can be attacked by third persons while in transport, a diligent entrepreneur will abstain from using the respective electronic infrastructure." (see WEBER (supra note 19), 845 seq., 850).

24 A general overview is given by RoLF H. WEBER / ANNETTE WILLI, IT-Sicherheit und Recht (Zürich 2006), 83 seq.

25 TheO HAERDER / ANDREAS ReUTER, Principles of Transaction-Oriented Database Recovery (1983), available at http://delivery.acm.org/10.1145/10000/291/p287haerder.pdf?key1=291\&key2=1679893031\&coll=DL\&dl=ACM\&ip=130.60.119.136\&CFID $=18319281 \&$ CFTOKEN $=60038319$.
} 
techniques: Write ahead logging and shadow paging; in both cases, locks must be acquired on all information that is updated, and depending on the level of isolation, possibly on all data. Guaranteeing ACID properties in a distributed transaction across a distributed database where no single node is responsible for all data affecting a transaction presents additional complications.

Another technology is radio-frequency identification (RFID) ${ }^{26}$ using communication via radio waves to exchange data between a reader and an electronic tag attached to an object, for the purpose of identification and tracking. Logistics and transportation are areas of implementation for RFID technology ${ }^{27}$.

Security controls for appropriate information security encompass aspects of identification, user provisioning, authorization, access control, audit and logging, encryption, etc.

\section{b) Data Retention and Electronic Archiving}

Data should be maintained in the Single Window not any longer than necessary to avoid increasing the risk of exposure ${ }^{28}$. At the same time, the retention of certain data or information for future reference may be necessary to meet certain legal requirements, for example, related to controversies that may later arise regarding the accuracy of information, dispute resolution and/or law enforcement. Therefore, data retention

26 See Rolf H. Weber / Romana Weber, Internet of Things: Legal Perspectives (Zürich/Berlin 2010), 2 seq.

27 For example in the Netherlands, the Dutch Government sponsors an RFID project in which Cargobox Europe B.V. tests an intelligent air cargo container. The container has a semiactive, or battery-assisted, tag and can be followed by a series of fixed and handheld readers that will be used in the warehouses of partners throughout the supply chain. This track-andtrace capability is achieved by a web-based IT platform which allows authorized users to view relevant Cargoboxes. The intelligence is in the RFID tags but also in the GPS, GSM, GPRS and airplane detection module that switches off the tag and sensors when the container is airborne, see http://www.cargo-box.com/.

28 Data protection is related to privacy (personal data protection) and therefore everything what is done has to be in compliance with all relevant privacy and personal data protection laws. But the interpretation of the right to privacy varies in the different parts of the world and so does the data protection law. The highest level of international consensus is reflected in the OECD Guidelines on the Protection of Privacy and Transborder Flows of Personal Data, Recommendation of the Council concerning guidelines governing the protection of privacy and the transborder flow of personal data (OECD, 23rd September 1980), available at

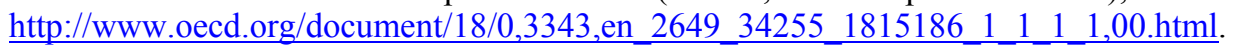


Weber: Legal Framework for the Single Window Concept in ASEAN

schedules should be worked out for each type of data in the system ${ }^{29}$. An example of records forbidden to be kept is that in Europe keeping some kinds of personal information may be a violation of Article 8 of the European Convention on Human Rights ${ }^{30}$. Specific provisions for disposal of data are to be developed and enforced ${ }^{31}$.

When it comes to the data processing within a Single Window facility it is necessary to determine for each step who is the data controller. Therefore, audit trails need to be established by means if identification, authentication, authorization as well as proper logging and recording mechanisms ${ }^{32}$.

Electronic archiving, a related concept, has substantially broader functionality than the Enterprise Content Management (ECM). The preserve components of ECM handle the long-term safe storage and backup of static information, as well as the contemporary storage of

29 It is important that a national legal regime permit the use of electronic documents to confirm that national law confirms the functional equivalence between a paper document and an electronic document, so that an electronic document (or record) is not denied validity for legal purposes (including court or other judicial proceeding) because of its is in electronic form. See also Thomas J. Smedinghoff, E-Transactions: The Key Rules for Ensuring Enforceability, Electronic Banking and Commerce Report, Vol. 11, No. 5 (Thompson/West Legal Works, 2006), available at http://www.wildman.com/article/E-Transactions _The Key Rules_For_Ensuring_Enforceability - June 06.pdf.

30 Convention for the Protection of Human Rights and Fundamental Freedoms, 4 Nov. 1950, CETS No. 5 (1950). In 1973, the Council of Europe, Communication of Ministers, Res. (73) 22 on the Protection of the Privacy of Individuals vis-à-vis Electronic Data Banks in the Private Sector, 26.09.1973, provided: "Rules should be laid down to specify the periods beyond which certain categories of information [stored in electronic data banks in the private sector] should no longer be kept or used." The Council of Europe's Convention on Data Protection provides in Article 5, "Personal data undergoing automatic processing shall be ... preserved in a form which permits identification of the data subjects for no longer than is required for the purpose for which those data are stored." Council of Europe, Convention for the Protection of Individuals with Regard to Automatic Processing of Personal Data, Strasbourg, 28 Jan. 1981, entered into force 1 Oct. 1985, CETS No. 108; Amendments to the Convention for the Protection of Individuals with Regard to Automatic Processing of Personal Data, Strasbourg, 15 June 1999; Additional Protocol to the Convention for the Protection of Individuals with Regard to Automatic Processing of Personal Data Regarding Supervisory Authorities and Transborder Data Flows, Strasbourg, 8 Nov. 2001, entered into force 1 July 2004, CETS No. 181.

31 See for further details, DAVID SATOla / William J. LudDY JR., The Potential for an International Legal Approach to Critical Information Infrastructure Protection, 47 Jurimetrics J (2007). 315 seq., available at http://www.uncitral.org/pdf/english/colloquia/EC/Satola_LuddyArticleRev.pdf.

32 See Rec35 (supra note 8), 15. 
information that does not need to be archived. Electronic archiving systems generally consist of a combination of administration of their like records managements, imaging or document management, library services or information retrieval systems, and storage subsystems.

\subsection{Information Sharing and Data Protection}

The pervasive use of information technology in businesses has generated an unrelenting flow of data that must be managed. A challenge arising is the need to ensure that electronic records of business activities are captured, retained and managed in a way that complies with a variety of regulations.

Apart from the human right to privacy which is stated in several international covenants of fundamental rights, a number of recommendations and guidelines are in place attempting to increase the level of data protection, for example the United Nations Guidelines for the Protection of Personal Data $(1990)^{33}$, the OECD Guidelines on the Protection of Privacy and Transborder Flows of Personal Data $(1980)^{34}$, the OECD Recommendations on Electronic Authentication and OECDGuidance for Electronic Authentication (2007) ${ }^{35}$, the Council of Europe Convention No. 108 on the Protection of Personal Data $(1980)^{36}$, the EU Directive on the Protection of Personal Data $(1995)^{37}$, the EU Directive on the Protection of Personal Data in Electronic Communications (2002) ${ }^{38}$.

33 See http://www.un.org/documents/ga/res/45/a45r095.htm.

34 See with further informarions:

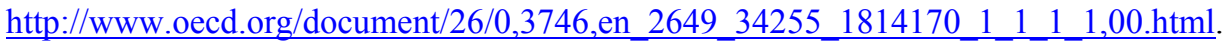

35 See http://www.oecd.org/document/7/0,3343,en_2649 $34255 \quad 38909639 \quad 1 \quad 1 \quad 1 \quad 1,00 . h t m l$.

36 See http://conventions.coe.int/Treaty/en/Treaties/Html/108.htm.

37 Directive 95/46/EC of the European Parliament and of the Council of 24 October 1995 on the protection of individuals with regard to the processing of personal data and on the free movement of such data, see

http://eur-lex.europa.eu/LexUriServ/LexUriServ.do?uri=CELEX:31995L0046:EN:HTML.

38 Directive 2002/58/EC of the European Parliament and of the Council of 12 July 2002 concerning the processing of personal data and the protection of privacy in the electronic communications sector (Directive on privacy and electronic communications), see http://eurlex.europa.eu/LexUriServ/LexUriServ.do?uri=CELEX:32002L0058:EN:HTML. The European Commission provides elaborate information regarding data protection on its website: http://ec.europa.eu/justice/policies/privacy/index en.htm. 
Weber: Legal Framework for the Single Window Concept in ASEAN

The level of data protection is not harmonized amongst the countries $^{39}$; nevertheless, some general principles based on statutory law or on self-regulation ${ }^{40}$, seem to be accepted on a global scale:

- Accuracy of data: Personal data must be accurate and, where necessary, kept up to date, to avoid any inaccurate (incorrect or misleading as to any matter of fact) data. Inaccurate data that accurately record the information given do not contravene this principle, if reasonable steps are taken to ensure their accuracy and if any notification of inaccuracy made by the data subject is included.

- Proportionality of data collection: In relation to the purpose or purposes for which data are processed, personal data shall be adequate, relevant and not excessive; it must therefore be checked that any stored personal data meets these criteria.

- Objective-orientation of data collection: Personal data shall be obtained only for one or more specified and lawful purposes meaning that these data should not be further processed in any manner incompatible with that original purpose or those purposes. To comply with this requirement it must be checked whether or not a purpose for obtaining the data has been specified. The person concerned should have been informed of this purpose and it must be ensured that the specified purpose is lawful.

- Privacy impact assessment: Personal data must be processed in accordance with the rights of data subjects. Data subject rights also include the prevention of processing for direct marketing purposes, rights related to automated decision-taking and the prevention of processing which is likely to cause damage or distress.

- Access of data: Data subjects have a number of rights, the foremost of which is usually a right to have access to their personal data.

\footnotetext{
39 For an overview looking at East Asian Countries, see GABRIELA KENNEDY / SARAH DoYLE/ BRENDA LUI \& CONTRIBUTORS, Data protection in the Asia-Pacific region, Computer Law \& Security Report, 25(1) (2009), 58 seq.

40 For the implementation of them two different approaches in Easat Asia, see WARREN CHIK, The Lion, the Dragon and the Wardrobe Guarding the Doorway to Information and Communications Privacy on the Internet: A Comparative Case Study of Hong Kong and Singapore - Two Differing Asian Approaches, International Journal of Law and Information Technology, Vol. 14, No. 1 (2005), 47 seq.
} 


\subsection{Electronic Signatures}

\section{a) Encryption as Technical Framework}

In the world of electronic transactions, security can only be achieved if the traditional signature is replaced by a reliable electronic signature ${ }^{41}$. Possible techniques are symmetric cryptosystems, asymmetric cryptosystems, passwords and tokens, biometrics, authentication procedures $^{42}$.

The security and assurance of any e-signature system depends on its entire infrastructure, and thus no e-signature methods can be said, on its own, to be secure ${ }^{43}$. However, e-signature infrastructure can be made secure to any desired level of assurance, just as a person's identity can be investigated to any degree desired. Tradeoffs include complexity, ease of use and cost. One distinct benefit of some e-signature systems is that their setup allows for the investigation into identity and authority to be carried out in advance of the withdrawal transaction. However, changes in authority might not be picked up unless the system builds in an additional track. Where signers are unknown to relaying parties, some e-signature systems are designed to permit the investigation to be performed by third parties who are in a better position to determine identity and authority, either in terms of cost or assurance level ${ }^{44}$.

Many legal instruments are available trying to establish a legal framework for electronic signatures, for example the UNCITRAL Model Law on Electronic Signatures $(2000)^{45}$, the United Nations Convention on

41 See WEBER (supra note 19), 851 seq.

42 See WEBER / WILLI (supra note 23), 83.

43 See for further details: FAYE F. WANG, Law of Electronic Commercial Transactions (New York 2010), 77 seq.

44 See Weber / Willi (supra note 23), 96; StePhan MASON, Electronic Signatures in Law (Tottel 2nd ed. 2007); Jeremiah S. Buckley / John P. Kromer / MArgo H. K. TANK / R. DAVID WHITAKER, The Law of Electronic Signatures (2nd Edition, West Publishing, 2009).

45 UNCITRAL Model Law on Electronic Signatures with Guide to Enactment 2001, available at http://www.uncitral.org/pdf/english/texts/electcom/ml-elecsig-e.pdf. 
Weber: Legal Framework for the Single Window Concept in ASEAN

the Use of Electronic Communications in International Contracts $(2005)^{46}$, the European Union E-Signature Directive $(1999 / 93)^{47}$ and national laws ${ }^{48}$.

\section{b) Certification Authorities}

Added to the use of electronic signatures and cross-border authentication is the potential for third-party certification for electronic communications that are intended to increase the reliability of a digital signature. The combination of a digital signature and such third-party certification is often referred to as a "public key infrastructure" (PKI) ${ }^{49}$. One solution to security-problems is the use of one or more third parties to associate an identified signatory or the signatory's name with a specific public key. That third party is generally referred to as a "certification authority" or a "certification services provider" in most technical standards and guidelines ${ }^{50}$. Certification authorities within a PKI can be established in a hierarchical structure, where some certification authorities only certify other certification authorities, which provide services directly to users. In such a structure, some certification authorities are subordinate to other certification authorities. In other conceivable structures, all certification authorities may operate on an equal footing. In any large PKI, there would likely be both subordinate and superior certification authorities. Other

46 United Nations Convention on the Use of Electronic Communications in International Contracts, available at http://www.uncitral.org/pdf/english/texts/electcom/0657452 Ebook.pdf.

47 Directive 1999/93/EC of the European Parliament and of the Council of 13 December 1999 on a Community framework for electronic signatures, available at http://eurlex.europa.eu/LexUriServ/LexUriServ.do?uri=CELEX:31999L0093:en:HTML.

48 Example China: see JANE K. WINN / YuPIng Song, Can China Promote Electronic Commerce through Law Reform? Some Preliminary Case Study, Columbia Journal of Asian Law (2007), available at http://papers.ssrn.com/sol3/papers.cfm?abstract id=901849; WANG (supra note 43), 29 seq.

49 See for further details regarding electronic signature and authentication methods as well as cross-border use of electronic signature and authentication methods: UNITED NATIONS, UNCITRAL, Promoting confidence in electronic commerce: legal issues on international use of electronic authentication and signature methods, (Vienna, 2009), available at http://www.uncitral.org/pdf/english/texts/electcom/08-55698_Ebook.pdf.

50 See Stephen E. Blythe, Hong Kong Electronic Signature Law and Certification Authority Regulations: Promoting E-commerce in the World's "Most Wired" City, North Carolina Journal of Law \& Technology, Vol. 7 (2005), 1 seq. 
Asian Journal of Law and Economics, Vol. 2 [2011], Iss. 4, Art. 2

solutions may include, for example, certificates issued by relying $\operatorname{parties}^{51}$.

\subsection{Electronic Trade}

\section{a) Contractual Issues}

Already at an early stage of the Internet use for commercial transactions, the United Nations Commission on International Trade Law (UNCITRAL) began preparations for a model law dealing with questions relating to the conclusion and implementation of electronic contracts; in 1996, the UNCITRAL Model Law on Electronic Commerce was adopted ${ }^{52}$. Later, negotiations have been taken up by a working group of experts under the auspices of the UNITRAL, the result of which was a new multilateral treaty on e-contracts. On November 23, 2005, the United Nations General Assembly adopted the Convention on the Use of Electronic Communications in International Contracts ${ }^{53}$. Several countries, including China and Singapore, have signed the Convention; however, it is not yet in force because the sufficient number of ratifications has not been delivered ${ }^{54}$.

The Convention covers the scope of application, general provisions, the use of electronic communications as main part, and the

51 An example: The Pan-Asian E-Commerce Alliance (PAA) aims to promote and provide secure, trusted, reliable and value-adding IT infrastructure and facilities for efficient global trade and logistics. Members of the Pan-Asian E-Commerce Alliance are China International Electronic Commerce Center, CIECC (China); Tradelink Electronic Commerce Limited (Hong Kong, China); TEDI - Trade Electronic Data Interchange (Japan); TEDMEV (Macao, China); Dagang Net Technologies Sdn Bhd (Malaysia); Korea Trade Network (Republic of Korea); CrimsonLogic (Singapore); Trade-Van Information Services Company (Taiwan Province of China); and CAT Telecom Public Company Limited (Thailand). For the mutual recognition of PKI a PAA Certificate Authority has been commissioned as a framework. PAA has established a certificate policy authority - the PAA Policy Authority - to govern and oversee the usage of digital certificate for all electronic transactions among the PAA members.

52 See http://www.uncitral.org/uncitral/en/uncitral texts/electronic_commerce/1996Model.html.

53 See

http://www.uncitral.org/uncitral/en/uncitral texts/electronic commerce/2005Convention.html.

54 Actual status available at

http://www.uncitral.org/uncitral/en/uncitral texts/electronic_commerce/2005Convention_stat us.html. 
Weber: Legal Framework for the Single Window Concept in ASEAN

final provisions 55 . The most important provision (Article 8) states that "a contract shall not be denied validity or enforceability on the sole ground that it is in the form of an electronic communication". Therefore, an electronic contract entered into via interactive websites is valid and enforceable. Further rules encompass the description of the electronic offer, the time and place of contract formation, and the electronic error. Consequently, the Convention improves the predictability and certainty of legal consequences of business transactions ${ }^{56}$. Previously at the national and international level, the directives, model laws and conventions governing electronic commercial transactions have not clearly stated when offers and acceptances of offers become effective for purposes of contract formation ${ }^{57}$.

\section{b) E-Documents of Title}

Similar developments as related to e-contracts in general can be seen in view of e-documents of title ${ }^{58}$. A bill of lading has commonly three characteristics $^{59}$, namely a contract for the carriage of the goods, an acknowledgement of their receipt, and a documentary evidence of title. In the meantime, the contents and format for bills of lading have been standardized and e-bills of lading are generally accepted (for example in

55 See JosÉ A. E. FARIA, The United Nations Convention on the Use of Electronic Communications in International Contracts - An Introductory Note, International and Comparative Law Quarterly 55 (July 2006), 691; PAUl PRZEMYSLAw POLANSKI, International electronic contracting in the newest UN Convention, Journal of International Commercial Law and Technology Vol. 2, Issue 3 (2007), 112 seq.; WEBER (supra note 19), 864 seq. The UN Convention does not include a provision on when an offer and acceptance in electronic form takes effect, and whether the existing rule of the time of dispatch and receipt of electronic communications will be sufficient to ascertain an offer and acceptance.

56 See Amelia H. Boss / WolfGang Kilian, The United Nations Convention on the Use of Electronic Communications in International Contracts (London 2008) as a guide and resource on the convention, its evolution, interpretation, and relationship to domestic laws throughout the world.

57 Regarding electronic contracts also see: LARRY DI MATTEO, Law of Internet Contracting, ( $2^{\text {nd }}$. ed. Austin 2009), 415 seq.; ChARLES H. KENNEDY, Making Enforceble Online Contracts, CRi 2/2009, 38 seq.; WANG (supra note 43), 29 seq; REBECCA ONG, Consumer Based Electronic Commerce: A Comparative Analysis of the Position in Malaysia and Hong Kong, International Journal of Law and Information Technology (Oxford 2004), 101 seq.

58 See LUDDY (supra note 11), 22 seq.

59 See $\quad \underline{\text { http://www.droit.univ-nantes.fr/labos/cdmo/centre-droit-maritime- }}$ oceanique/cdmo/neptunus/nept/nep32/32 3.pdf. 
the Hamburg Rules $\left.{ }^{60}\right)^{61}$. The usual steps of conclusion of a contract are also applicable in respect of e-bills of lading even in case of a three party contract $^{62}$.

A similar development can be seen in respect of the letters of credit, usually issued on the basis of the International Chamber of Commerce Uniform Customs and Practice for Documentary Credits (UCP $600^{63}$ ): An e-letter of credit can be used for trade finance. As an example, the Hong Kong based enterprise Bolero can be mentioned: Bolero is the leading global provider of multi-bank trade finance solutions, delivered through a combination of functionally rich multi-bank trade finance applications and neutral, secure and legally binding electronic communication channels. Bolero provides electronic communication channels and application solutions for the management of export letters of credit, import letters of credit, guarantees, documentary collections and supply chain finance. The Bolero ${ }^{64}$ messaging infrastructure consists of a

60 See http://www.jus.uio.no/lm/un.sea.carriage.hamburg.rules.1978/. In the Hamburg Rules it is only stated that the signature on the bill of lading may be in handwriting or made by any other electronic means.

61 GEORGIOS ZEKOS, EDI and the contractual role of computerized (electronic) bills of lading, Managerial Law, Vol. 41 No. 6 (1999), 1 seq.

62 See also Judith Y. GLINIECKI / CEDA G. OGADA, The Legal Acceptance of Electronic Documents, Writings, Signatures, and Notices in International Transportation Conventions: A Chalenge in the Age of Global Electronic Commerce, Northwestern Journal of International Law \& Business, Vol. 13 (1992), 117 seq.

63 The evolution of the UCP towards accommodation of electrification began with UCP400 and gradually increased to the point where the drafters of the UCP faced the question of what to do about the possibility of electronic performance, that is, the presentation of electronic documents. Rather than revising or altering the UCP regime, it was decided to create a supplemental set of rules which were labeled the eUCP [Supplement to the Uniform Customs and Practice for Documentary Credits (UCP 500) for Electronic Presentation, Version 1.1 (2002) was aligned with UCP500 (1993). eUCP Version 1.1, Supplement to UCP600 for Electronic Presentation (2007) is aligned with UCP600 (2007)]. Originally released in 2002 as a supplement to UCP500, they were revised in 2007 to supplement UCP600. These rules contain a scheme by which both paper and electronic documents can be presented. The scheme can determine issues regarding authenticity, allocate risk of nonreceipt of an electronic communication as well as address questions related to notice of refusal, originality and copies, date of issuance, transport, and the corruption of an electronic record after it has been presented. See JAMES E. BYRNE, The Four Stages in the Electrification of Letters of Credit, 10, available at

www.uncitral.org/pdf/english/.../EC/UN_4_stages_UNCITRAL_Byrne.doc.

Also see http://www.iccbooks.com for various publications on UCP.

64

See http://www.bolero.net/home.aspx for furthr details. 
Weber: Legal Framework for the Single Window Concept in ASEAN

core messaging platform, comprehensive multi-bank XML standards, the Title Registry and the multi-party legal Rulebook.

\subsection{Intellectual Property Rights}

The Paris Convention for the Protection of Industrial Property $(1883)^{65}$ is the principle international agreement in the field of industrial property, including patents, trademarks, models and industrial designs. The Paris Convention provides the same rights to national and foreigners and establishes the right of priority. The Berne Convention for the Protection of Literary and Artistic Works $(1886)^{66}$ requires member states to provide protection for every production in the literary, scientific and artistic domain. The WIPO Patent Cooperation Treaty $(1970)^{67}$ provides for a unified procedure for filing patent applications to protect inventions in each of the contracting states. The WIPO Copyright Treaty $(1996)^{68}$ is an international treaty on copyright law adopted in order to better realize copyright protection in the Internet. The WIPO Patent Law Treaty $(2000)^{69}$ aims at harmonizing formal procedures in patent matters such as the requirements to obtain a filing date for a patent application, the form and content of a patent application, and representation.

From the general principles of intellectual property rights (IPR) ${ }^{70}$ the following elements play a particular role in the Single Window content:

- Territoriality: IPR protection is principally limited to territorial nations; co-operation between states can help to overcome different levels of protection.

- Exclusivity: IPR grant an exclusive position; Single Window regulations should be designed in a way that this exclusivity does not negatively interfere with the efficient handling of e-transactions.

65 See http://www.wipo.int/treaties/en/ip/paris/trtdocs_wo020.html.

66 See http://www.wipo.int/treaties/en/ip/berne/trtdocs_wo001.html.

67 See http://www.wipo.int/pct/en/texts/articles/atoc.htm.

68 See http://www.wipo.int/treaties/en/ip/wct/trtdocs wo033.html.

69 See http://www.wipo.int/treaties/en/ip/plt/trtdocs_wo038.html.

70 See also TRIPS (Agreement on Trade-Related Aspects of Intellectual Property Rights) http:/www.wto.org/english/tratop_e/trips_e/t agm2 e.htm. TRIPS is an international agreement administered by the WTO that sets down minimum standards for many forms of IP-regulation as applied to nationals of other WTO Members. It was negotiated at the end of the Uruguay Round of the GATT in 1994. 
- Protection of software: The IPR exclusivity-demand is of particular relevance for software; on the one hand, sophisticated programs should be protectable, on the other hand, the risk of overprotection of standard software must not be underestimated.

- Protection of business methods: Similarly as in case of software, the kind of IPR-protection should meet individual research requirements, but not jeopardize the execution of e-transactions.

In addition, the European Union knows a Database Directive $(1996)^{71}$, recognizing a sui-generis intellectual property right in favor of the owner of a database. These database rights last for 15 years, and can be extended if the database is updated. An owner has the right to object to the copying of substantial parts of their database, even if data is extracted and reconstructed piecemeal. Database rights under the EU rules are created automatically, vested in the employers of creators, and do not have to be registered to that effect.

For the protection of knowledge, there are only two options to ensure that know-how remains valuable: The first is secrecy, but once secrecy is breached, the floodgates are open; to try to ensure that secrecy is observed, professional parties often enter into a confidentiality agreement or a non-disclosure agreement. Although this agreement may provide a mechanism to get compensation, it does not guarantee that certain know-how will remain secret. Indeed there is a risk the secrecy will be breached soon or later. If know-how meets the requirements of an intellectual property law, then know-how can enjoy the respective protection.

\subsection{Liability Issues}

Potential for legal liability can arise in several contexts in the Single Window operation ${ }^{72}$. Central are those risks which rely to data processing errors and possible data breaches. Data processing errors can result in monetary losses to the parties using Single Window facilities. The technological development of the Single Window has to minimize the potential for damages and so to avoid injuries related to problems in the

71 Directive 96/9/EC of the European Parliament and of the Council of 11 March 1996 on the legal protection of databases.

http://eur-lex.europa.eu/LexUriServ/LexUriServ.do?uri=CELEX:31996L0009:EN:HTML.

72 See Rec35 (supra note 8), 13; SCHERMER (supra note 22), 5; LUDDY (supra note 11). 13. 
Weber: Legal Framework for the Single Window Concept in ASEAN

area of information sharing. The use of inaccurate, incomplete, or incorrect data by Single Window participants can lead to multiple cases in which damages may occur. The respective risks should not be underestimated since SW-participants who suffer damages may seek recourse from the Single Window operator. Furthermore, the growing challenges regarding cybercrime ${ }^{73}$ and cybersecurity are to be addressed to avoid liability issues ${ }^{74}$.

Liability issues must be examined for the legal infrastructure of the Single Window, so that the potential for legal recourse at both the national and international levels can be addressed. The agreements between the Single Window facility and the end-users can regulate such issues and include provisions for the limitation of liabilities and indemnification for damages. Similarly, at the international level, agreements between Single Window operators that are interacting together should address these issues. Governments establishing a Single Window facility may consider using agreements that include alternative dispute resolution mechanisms to avoid the possibility of costly litigation.

73 ITU, the leading United Nations agency for information and communication technology issues, launched in May 2007 the Global Cybercrime Agenda (GCA) with the idea to coordinate the international response to growing challenges to cybersecurity. The also in 2007 established global High-Level Experts Group (HLEG) delivered the Chairmans Report in August 2008 with recommendations, including on cyber crime legislations. The Global Strategic Report (available at

http://www.itu.int/osg/csd/cybersecurity/gca/global strategic report) was delivered in November 2008, including strategies in five work areas: Legal measures, Technical and prosedural measures, Organizational structures, Capacity building, and International cooperation. The Council of Europe Convention on Cybercrime (2001), which is a regional initiative, could be used as a guideline, or as a reference for developing internal legislation, by implementing the standards and principles it contains, in accordance with the local legal system and practice (Articles of the Council of Europe Convention on Cybercrime and the Explanatory Report to the Convention may be found at the website http://conventions.coe.int/Treaty/EN/Reports/Html/185.htm). The Convention on Cybercrime was the first international treaty seeking to address Computer crime and Internet crimes by harmonizing national laws, improving investigative techniques and increasing cooperation among nations.

74 See also Stein Schjolberg / Solange Ghernaouti-Hélie, A Global Protocol on Cybersecurity and Cybercrime (Oslo 2009), available at

http://www.cybercrimelaw.net/documents/A_Global_Protocol_on_Cybersecurity_and_Cyber crime.pdf, with a detailed proposal for a preliminary Model Law on Cybercrime Legislation based on the recommendations that were adopted in a broad agreement by the global High Level Experts Group (HLEG), and recommendations on additional provisions due to the technological development since 2001. 


\subsection{Dispute Resolution Mechanisms}

Due to the costs of state court litigation and (usually) of arbitration, Alternative Dispute Resolution (ADR $)^{75}$ provisions gained importance, in particular if the value at stake is not very high. ADR is generally classified into at least four types, namely negotiation, mediation, collaborative law, and arbitration ${ }^{76}$. To provide a fast executing and reliable ADR, the special issues of international trade are to be addressed in the context of Single Window operations.

There are different opinions on costs and time of arbitration, while often is said, arbitration is cheaper and quicker than court litigation, opponents to arbitration argue that arbitration is becoming akin to litigation and expensive. Sometimes arbitrators tend to «split the baby» and they might be less reliable than courts $^{77}$. The increasing sophistication, and the transfer of court litigations practices into arbitration, while setting aside old healthy arbitration usages, can cause arbitration to become more expensive and time consuming. Due to the confidentiality nature of arbitration, there are little hard data around related to time incurred and costs spent in international arbitration ${ }^{78}$.

75 See Rec35 (supra note 8), 13.

76 See POMPeU CaSAnovas, Legal Electronic Institutions and ONTOMEDIA: Dialogue, Inventio, and Relational Justice Scenarios, in: AI Approaches to the Complexity of Legal Systems. Complex Systems, the Semantic Web, Ontologies, Argumentation, and Dialogue (Berlin 2010), 184 seq.; MARTA Poblet / PomPeu Casanovas / José Manuel LóPez-Cobo / Alvaro Cabrerizo / Juan Antonio Prieto, Mediation, ODR, and the Web 2.0: A Case for Relational Justice, in: AI Approaches to the Complexity of Legal Systems. Complex Systems, the Semantic Web, Ontologies, Argumentation, and Dialogue (Berlin 2010), 205 seq.

77 Three reasons that cause arbitration to reduce substantially the risks, costs and time in international litigation: (i) Arbitration clauses eliminate forum shopping, which is one of the worst evils of international litigation; parties that agreed arbitration are entitled to request local courts to refer the parties to arbitration and forum disputes in different countries are avoided. (ii) Service of a request for arbitration does not require court intervention, rogatory letters or other formalities; only simple delivery. (iii) Foreign arbitral awards are enforceable under the New York Convention, while there is not a universal similar treaty on the enforcement of foreign judgments [(United Nations Convention on the recognition and enforcement of foreign arbitral awards ("New York Convention" or "NYC") Articles III and $\mathrm{V}$, National enforcements of the UNCITRAL Model Law on International Commercial Arbitration ("UMLA"), articles 8, 35 and 36, and other advanced national arbitration laws]. José M. A. ZAMORA, Reducing Time and Costs on International Arbitration (Vienna 2007), available at http://www.uncitral.org/pdf/english/congress/Abascal-rev.pdf.

78 Regarding costs see the report from the ICC Commission on Arbitration, Techniques for Controlling Time and Costs in Arbitration ("ICC Report"), (www.iccwbo.org). According to the ICC Report, $2 \%$ of the cost of arbitration is spent in administrative expenses of the ICC 
Weber: Legal Framework for the Single Window Concept in ASEAN

In East Asia generally, disputes in relation to economic agreements are to be resolved in accordance with the terms of the ASEAN Protocol on Enhanced Dispute Settlement Mechanisms ${ }^{79}$, which is in force since November 29, 2004. The ASEAN national customs and trade authorities coordinate their activities; as the Secretariat has no legal authority to resolve such disputes, and if a bilateral resolution by informal means is not possible, the Enhanced Dispute Settlement Mechanisms may apply. Members can seek mediation and "good offices" consultations; if these efforts are ineffective, Members may call the Senior Economic Officials' Meeting to establish a panel of independent arbitrators to review the dispute. Panel decisions can be appealed to an Appellate Body formed by the Economic Community Council. However, so far the Protocol has almost never been invoked.

\section{Implementation of Single Window}

\subsection{Political and Legal Environment}

The successful Introduction and Implementation of a Single Window concept depends to a considerable extent on certain pre-conditions and success factors that vary from country to country and from project to project. The following list of factors and elements need to be taken into consideration $^{80}$ :

- Political will: Both governments and businesses should be interested to implement a Single Window, make the necessary resources available and agree on the proper dissemination of clear and impartial information.

- Partnership between government and trade: The successful implementation of a Single Window makes it necessary that all

Court, $16 \%$ in arbitrators' fees and expenses. The rest, $82 \%$, is spent in costs borne by the parties to present their cases; "including, as the case may be, lawyers' fees and expenses, expenses related to witness and expert evidence, and other costs". These data show that the major cause of escalation of costs and increase in time spent is not a problem particular to arbitration. Most probably it is due to litigation practices and strategies, rather than costs inherent and peculiar to the arbitration procedure.

79 See http://www.aseansec.org/16754.htm.

80 This subsection is based on Rec 33 (supra note 4), 15 seq. 
relevant public and private agencies and organizations participate in the development of the system and the involvement in its processes.

- Definition of clear project objectives: The Single Window implementation must be based on a careful analysis of the needs, aspirations and resources of the key stakeholders, in particular in respect of the given infrastructure.

- User friendliness and accessibility: A Single Window concept should encompass the requirements of adequate operating guidelines, support services (including training) and help desk services.

- Strong lead agency: The implementation of a Single Window concept is more likely if a strong, resourceful and empowered lead organization is driving the project.

- Financial model, promotion and communication: Clear guidelines as to the financing of a single model are needed. Furthermore, promotion of a Single Window concept is very important and should be carefully planned. Any marketing campaign should involve representatives from all key organizations and agencies. In addition, establishing a proper mechanism for keeping all stakeholders informed on project goals, objectives, targets, progress and difficulties of a concept creates trust and avoids misunderstandings.

- Payment possibility: The inclusion of possible payment mechanisms makes a Single Window concept more attractive.

- Legally-enabling environment: As mentioned, legal issues and restrictions are to be identified and carefully analysed; a clear and predictable legal environment leads to trust of the involved stakeholders.

\subsection{Lessons from Experiences}

Some Single Window experiences have already been made; a very good example is TradeNet which has greatly improved and streamlined the trade process which was vital to the Singapore's economy. Besides many other benefits the following achievements were accomplished $^{81}$ :

81 See http://www.unece.org/cefact/single window/sw cases/Download/Singapore.pdf for further details. 
Weber: Legal Framework for the Single Window Concept in ASEAN

- Faster response to facilitate dynamic enforcement and implementation of rules and regulations, so that urgent implementation of regulatory and policy changes can be done quickly and with accurate enforcement assisted by the system (e.g. restrictions to import specific type of goods to/from certain countries due to, say, outbreak of diseases).

- Improvement of accurate and prompt collection of trade statistics, leading to an effective and timely data-base fostering analysis of tradingdevelopments and forecasting of trading trends.

- Improved customer service with 24 / 7-service-accessibility so that users can gain access to the system from any location as it is a web-based application.

- Ease of use (user-friendly web portals) and increased efficiency (based on one permit application for submission to various agencies) so the productivity level increased as a result of the shortened turnaround time for the processing of trade declarations.

- Maintenance and easy deployment: Processing and validation rules are tied to political, social and environmental changes (a rules engine can be easily updated so any change will only produce a file-update on the server).

- Cost effectiveness for users and service providers: (i) Users can access the Single Window facility with their existing workstations and Internet connections (no further costs for software and maintenance), leading to a decrease of business operating costs (i.e. warehouse storage charges) due to the reduction of delays in documentation combined with lower manpower cost with the simplified processes and high system availability. (ii) Service providers benefit form an optimised hardware setup resulting in an efficient way to manage the operating and maintenance cost.

- Ease of integration and connectivity based on the use of leadingedge technology allows integration with trading partners and authorities.

- Ease of Future development to cater for local trade growth and international trade information exchange based on (i) hardware scalability depending on the processing performance expectation and transaction volume as well as (ii) software portability and reusability.

\section{Outlook}

The increased re-use of data along the supply chain and the combination with assistance in the fields of logistics, trade insurance and finance as well as purchasing and warehouse solutions to the trading community as a bundle together with permit preparation module will increase efficiency in the near 
future. The permit preparation module promotes data sharing and reduces data redundancy or repeated data entries.

Solutions coming together as a bundle on the same platform will improve information sharing between the different applications to provide a seamless flow of information between the different applications with the external logistic partners, governmental authorities and also within each company's business process flow by minimising the need for repeated data entry on the same piece of cargo information. 